\title{
Dissolved organic sulfur in streams draining forested catchments in southern China
}

\author{
Zhanyi Wang ${ }^{1,2}$, Xiaoshan Zhang ${ }^{1, *}$, Zhangwei Wang $^{1}$, Yi Zhang ${ }^{1}$, Bingwen $^{2}{ }^{1}$, Rolf Vogt ${ }^{3}$ \\ 1. Research Center for Eco-Environmental Sciences, Chinese Academy of Sciences, Beijing 100085, China. E-mail: zhanyiwang2006@ 163.com \\ 2. College of Ecology and Environmental Science, Inner Mongolia Agricultural University, Hohhot 010018, China \\ 3. Department of Chemistry, University of Oslo, P.O.BOX 1033, Blindern, N-0315 Oslo, Norway
}

Received 03 April 2011; revised 19 May 2011; accepted 26 May 2011

\begin{abstract}
Dissolved organic sulfur (DOS) is an important fraction for sulfur mobilization in ecosystem. In this work stream waters were sampled in 25 forested sites in southern China to study the dissolved sulfur fractions. Dissolved sulfur was fractionated into dissolved organic sulfur (DOS) and inorganic sulfate $\left(\mathrm{SO}_{4}^{2-}\right)$ for 95 stream water samples. The results showed that the concentration of DOS ranged from 0 to $13.1 \mathrm{mg} / \mathrm{L}$ (average $1.3 \mathrm{mg} / \mathrm{L}$ ) in all the streams. High concentrations of DOS in stream waters were found in the sites with high concentrations of sulfate. DOS constituted less than $60.1 \%$ of dissolved sulfur (average 17.9\%). Statistical analysis showed that DOS concentration was correlated with $\mathrm{SO}_{4}^{2-}$ in streams waters and total sulfur in surface layer soils. The results also showed that DOS concentration in stream waters had a seasonal variation, but no trends were found with it. The implication was that the long term sulfur deposition had led the increase of the concentration and fraction of DOS in stream waters in acid rain prevailing regions
\end{abstract}

Key words: dissolved organic sulfur; stream water; Chinese forests; sulfur deposition

DOI: $10.1016 / \mathrm{S} 1001-0742(11) 60781-\mathrm{X}$

\section{Introduction}

Dissolved natural organic matter (DNOM) is a continuum of organic molecules of different sizes and structures that pass through a $0.45 \mu \mathrm{m}$-pore size filter (Kalbitz et al., 2000; Zsolnay, 2003). DNOM plays an important role in soil formation (Dawson et al., 1978), mineral weathering (Raulund-Rasmussen et al., 1998) and transport of pollutants (Kalbitz et al., 1997; Marschner, 1998; Temminghoff et al., 1997). Approximately half mass of DNOM is constituted by carbon. The concentration of dissolved organic carbon is therefore commonly used as a proxy for DNOM. The rest is mainly made up by oxygen and hydrogen, along with varying content of nitrogen and sulfur, and a minor content of phosphorous. DNOM is therefore also important in the transport of nutrients from soil to surface waters (Neff et al., 2003). There were many studies describing the content of the primary macronutrient nitrogen in soil and groundwater DNOM (Christou et al., 2006; Jones et al., 2004; Kroeger et al., 2006; LoriteHerrera et al., 2009; Yue et al., 2008; Wu et al., 2010), but the literature regarding the content of the secondary macronutrient sulfur in DNOM, dissolved organic sulfur (DOS) was much less.

Sulfur in DNOM occurs as reduced (e.g., sulfide and thiol) or as oxidized species (e.g., sulfonate and sulfate).

\footnotetext{
* Corresponding author. E-mail: zhangxsh@rcees.ac.cn
}

Several studies on the transport of mercury $(\mathrm{Hg})$ from soils to surface waters have focused on the amount and form of sulfur in DNOM since the reduced sulfur sites in DNOM are found to be important for mercury binding (Amirbahman et al., 2002; Haitzer et al., 2002; Skyllberg et al., 2000).

A few studies indicate that $10 \%-20 \%$ of dissolved sulfur content in soil and groundwater could be bound to DNOM (Nilsson et al., 2001; Mitchell et al., 1986, 1989). DOS may therefore in some cases constitute a significant part of the total flux of sulfur from terrestrial to aquatic environment. Nevertheless, the sulfur flux calculations are commonly based solely on sulfate $\left(\mathrm{SO}_{4}^{2-}\right)$ - assuming that DOS is present in only minor amounts. In a few cases the content of DOS is roughly estimated based on an assumed fixed ratio to the amount of dissolved organic carbon (DOC) (Raue et al., 1991). In fact, the content of DOS in DNOM may vary considerably with season and space (Peuravuori et al., 2005). A sound understanding of the factors governing the temporal and spatial variation in DOS is therefore a prerequisite in order to make sound catchment budgets of sulfur.

Houle et al. (1995) found that the content of DOS in lake water DNOM was affected by sulfur loading in the form of acid deposition. Regional sulfur deposition increases the accumulation of sulfate adsorbed to the soil (Galloway et al., 1983) and thereby the amount of sulfur incorporated 
into the soil organic matter (Prietzel et al., 2004). There is therefore a specific need for a better understanding of the effects of sulfur deposition on the amount of DOS in stream water in the acid rain prevailing region in southern China, experiencing a changed sulfur deposition.

In this study, seasonal and spatial variation of the sulfur fractions, DOS and $\mathrm{SO}_{4}^{2-}$ were assessed based on sulfur fractionation results on 95 stream water samples from 25 small forested catchments in southern China, experiencing a span in sulfur loading.

\section{Materials and methods}

\subsection{Sampling and analysis}

Water samples were collected from 25 forested catchments in southern China (Fig. 1 and Table 1) during July to November in 2009 for a synoptic study of spatial variation

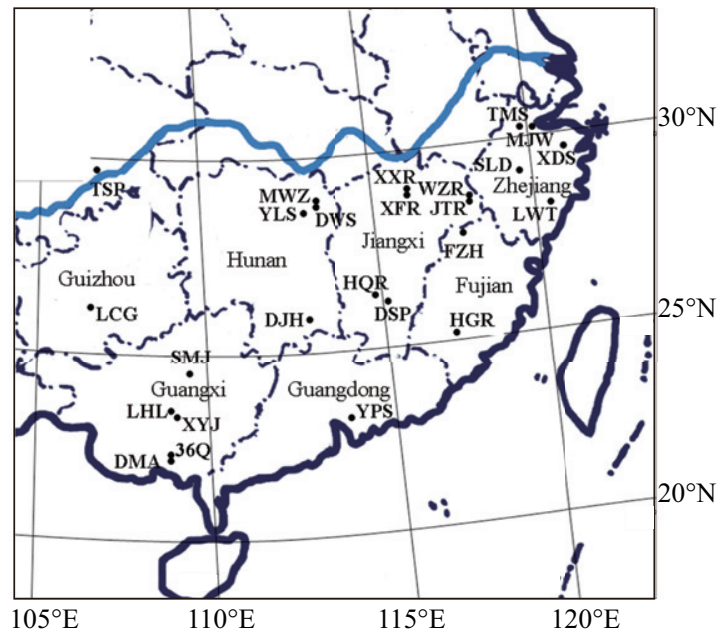

Fig. 1 Geographical distribution of sampling sites. in sulfur fractionation. Two to six water samples were collected from each catchment depended on local condition. Soils were also sampled from the surface layers in the recharge areas close to the streams. At sites YLS and MJW stream water samples were collected weekly in 2009 to obtain the seasonal fluctuations in stream water chemistry.

All water samples were filtered through $0.45 \mu \mathrm{m}$ filters and frozen at $-20^{\circ} \mathrm{C}$ prior to analysis. Dissolved sulfur (DOS plus sulfate) and major cations were analyzed according to ISO 11885 by inductively coupled plasma-optical emission spectroscopy (ICP-OES) (Prodigy, Leeman Labs, USA) with the optical system purged with argon. The line at $182.034 \mathrm{~nm}$ was selected for sulfur measurement (Prietzel et al., 1996). $\mathrm{SO}_{4}^{2-}$ and other major anions were analyzed using ion chromatography (IC) (DX-120, Dionex corporation, USA) according to ISO 10304-1. The same standards were used for calibration of the measurements by both ICP-OES and IC to minimize error. Thus DOS concentration (dissolved sulfur minus the sulfate) was obtained (David and Mitchell, 1985; Homann et al., 1990; Mitchell et al., 1986).

DOC was determined by a TOC analyzer (Phoenix 8000 UV-persulfate TOC analyzer, Tekmar Dohrmann, USA). The $\mathrm{pH}$ value was determined by a $\mathrm{pH}$ combination electrode (Rex E-201-C-9, Shanghai Rex, China) according to ISO 10523. Total-sulfur, -carbon and -nitrogen in the soil samples was determined by a $\mathrm{C} \backslash \mathrm{N} \backslash \mathrm{H} \backslash \mathrm{S}$ analyzer (Vario Elementar III, Elementar Analysensysteme GmbH, Germany) (Wang et al., 2006).

\subsection{Method for data analysis}

Statistical methods were utilized to assess the parameters influencing the DOS concentration. These parameters included pH, DOC, major anions and cations in water, and total-carbon, -nitrogen and -sulfur in soils. The statistical

Table 1 List of the catchments in this study

\begin{tabular}{|c|c|c|}
\hline Catchments (symbol) & Latitude/Longitude & Forest types \\
\hline Daowushan (DWS) & $28^{\circ} 12^{\prime} \mathrm{N} / 113^{\circ} 34^{\prime} \mathrm{E}$ & Coniferous forest \\
\hline Damaan (DMA) & $21^{\circ} 59^{\prime} \mathrm{N} / 108^{\circ} 36^{\prime} \mathrm{E}$ & Deciduous broadleaf forest \\
\hline Dashipan (DSP) & $25^{\circ} 48^{\prime} \mathrm{N} / 115^{\circ} 02^{\prime} \mathrm{E}$ & Evergreen broadleaf forest \\
\hline Dongjianghu(DJH) & $25^{\circ} 52^{\prime} \mathrm{N} / 113^{\circ} 18^{\prime} \mathrm{E}$ & Subtopic evergreen broadleaf forest \\
\hline Fengzhan Reservoir (FZR) & $27^{\circ} 22^{\prime} \mathrm{N} / 117^{\circ} 39^{\prime} \mathrm{E}$ & Mixed coniferous-deciduous forest \\
\hline Huanggang Reservoir (HGR) & $25^{\circ} 01^{\prime} \mathrm{N} / 116^{\circ} 54^{\prime} \mathrm{E}$ & Mixed coniferous-deciduous forest \\
\hline Hongqi Reservoir (HQR) & $25^{\circ} 56^{\prime} \mathrm{N} / 114^{\circ} 50^{\prime} \mathrm{E}$ & Evergreen broadleaf forest \\
\hline Juntan Reservoir (JTR) & $28^{\circ} 13^{\prime} \mathrm{N} / 118^{\circ} 16^{\prime} \mathrm{E}$ & Evergreen broadleaf forest \\
\hline Laohuling (LHL) & $22^{\circ} 56^{\prime} \mathrm{N} / 108^{\circ} 20^{\prime} \mathrm{E}$ & Deciduous broadleaf forest \\
\hline Longwantan (LWT) & $28^{\circ} 20^{\prime} \mathrm{N} / 120^{\circ} 52^{\prime} \mathrm{E}$ & Mixed coniferous-deciduous forest \\
\hline Luchongguan (LCG) & $26^{\circ} 26^{\prime} \mathrm{N} / 106^{\circ} 39^{\prime} \mathrm{E}$ & Mixed coniferous-deciduous forest \\
\hline Maweizhao(MWZ) & $28^{\circ} 21^{\prime} \mathrm{N} / 113^{\circ} 35^{\prime} \mathrm{E}$ & Mixed coniferous-deciduous forest \\
\hline Meijiawu (MJW) & $30^{\circ} 16^{\prime} \mathrm{N} / 120^{\circ} 12^{\prime} \mathrm{E}$ & Mixed coniferous-deciduous forest \\
\hline Sanmenjiang (SMJ) & $24^{\circ} 21^{\prime} \mathrm{N} / 109^{\circ} 29^{\prime} \mathrm{E}$ & Mixed coniferous-deciduous forest \\
\hline Shuanglongdong (SLD) & $29^{\circ} 12^{\prime} \mathrm{N} / 119^{\circ} 37^{\prime} \mathrm{E}$ & Mixed coniferous-deciduous forest \\
\hline 36Qu Forest Park (36Q) & $22^{\circ} 02^{\prime} \mathrm{N} / 108^{\circ} 37^{\prime} \mathrm{E}$ & Mixed coniferous-deciduous forest \\
\hline Tieshanping (TSP) & $29^{\circ} 38^{\prime} \mathrm{N} / 106^{\circ} 41^{\prime} \mathrm{E}$ & Mixed coniferous-deciduous forest \\
\hline Tianmushan (TMS) & $30^{\circ} 20^{\prime} \mathrm{N} / 119^{\circ} 26^{\prime} \mathrm{E}$ & Mixed coniferous-deciduous forest \\
\hline Xinfu Reservoir (XFR) & $28^{\circ} 41^{\prime} \mathrm{N} / 115^{\circ} 41^{\prime} \mathrm{E}$ & Evergreen broadleaf forest \\
\hline Xixia Reservoir (XXR) & $28^{\circ} 50^{\prime} \mathrm{N} / 115^{\circ} 47^{\prime} \mathrm{E}$ & Evergreen broadleaf forest \\
\hline Xiyunjiang (XYJ) & $22^{\circ} 58^{\prime} \mathrm{N} / 108^{\circ} 32^{\prime} \mathrm{E}$ & Deciduous broadleaf forest \\
\hline XueDouShan(XDS) & $29^{\circ} 40^{\prime} \mathrm{N} / 121^{\circ} 13^{\prime} \mathrm{E}$ & Coniferous forest \\
\hline Yuelushan (YLS) & $28^{\circ} 11^{\prime} \mathrm{N} / 112^{\circ} 55^{\prime} \mathrm{E}$ & Evergreen broadleaf \\
\hline Yinpingshan(YPS) & $22^{\circ} 52^{\prime} \mathrm{N} / 114^{\circ} 14^{\prime} \mathrm{E}$ & Mixed coniferous-deciduous forest \\
\hline Wangzai Reservoir (WZR) & $28^{\circ} 42^{\prime} \mathrm{N} / 118^{\circ} 04^{\prime} \mathrm{E}$ & Evergreen broadleaf forest \\
\hline
\end{tabular}


methods employed were a simple correlation analysis, stepwise multiple linear regression and partial least squares regression.

When co-linearity relationships exist between each independent variable, errors will occur in the results of linear regression. Therefore the partial least squares regression was utilized to reduce the errors (Guo et al., 2007).

\section{Results and discussion}

\subsection{DOS and sulfate concentrations in stream water at different sites}

The concentrations of dissolved sulfur (DOS plus sulfate) in the most of water samples were found to be less than $10 \mathrm{mg} / \mathrm{L}$ (Figs. 2 and 3). High concentrations of dissolved sulfur $(>10 \mathrm{mg} / \mathrm{L})$ in water samples were found at LCG in Guizhou, at TSP in Chongqing and at SMJ in Guangxi. These three sites have all been subjected to a heavy loading of sulfur deposition during the past several decades (Chen and Liu 1996; Larssen et al., 2006). At these sites the concentrations of DOS ranged from 4.4 to $13.1 \mathrm{mg} / \mathrm{L}$ and $\mathrm{SO}_{4}^{2-}$ from 6.2 to $33.6 \mathrm{mg} / \mathrm{L}$ (Fig. 3). The high concentrations of sulfate in these sites were linked with high concentrations of base cation leaching from soils. It may indicate that the soils in these sites had not capacity to adsorb extra amounts of sulfate. With the exception of the sites LCG, TSP and SMJ the DOS concentration were quite low with an average of $0.2 \mathrm{mg} / \mathrm{L}$ (Fig. 2), which were comparable to the concentrations $(0.2$ to $0.4 \mathrm{mg} / \mathrm{L})$ for fifty-nine lakes in Québec, Canada (Houle et al., 1995).

DOS accounted for average $15.5 \%$ (0 to $42.2 \%$ ) of the dissolved sulfur at the sites with low concentration $(<10 \mathrm{mg} / \mathrm{L})$ of dissolved sulfur in water samples. At the sites with high concentration of dissolved sulfur, DOS accounted for $12.8 \%$ to $60.1 \%$ of dissolved sulfur which was higher than the values (1\% to $18 \%$ ) in stream waters of the Adirondacks, USA (David and Mitchell, 1985) and the values $(12 \%$ to $21 \%)$ in stream waters of the Rocky Mountains (Mitchell et al., 1986).
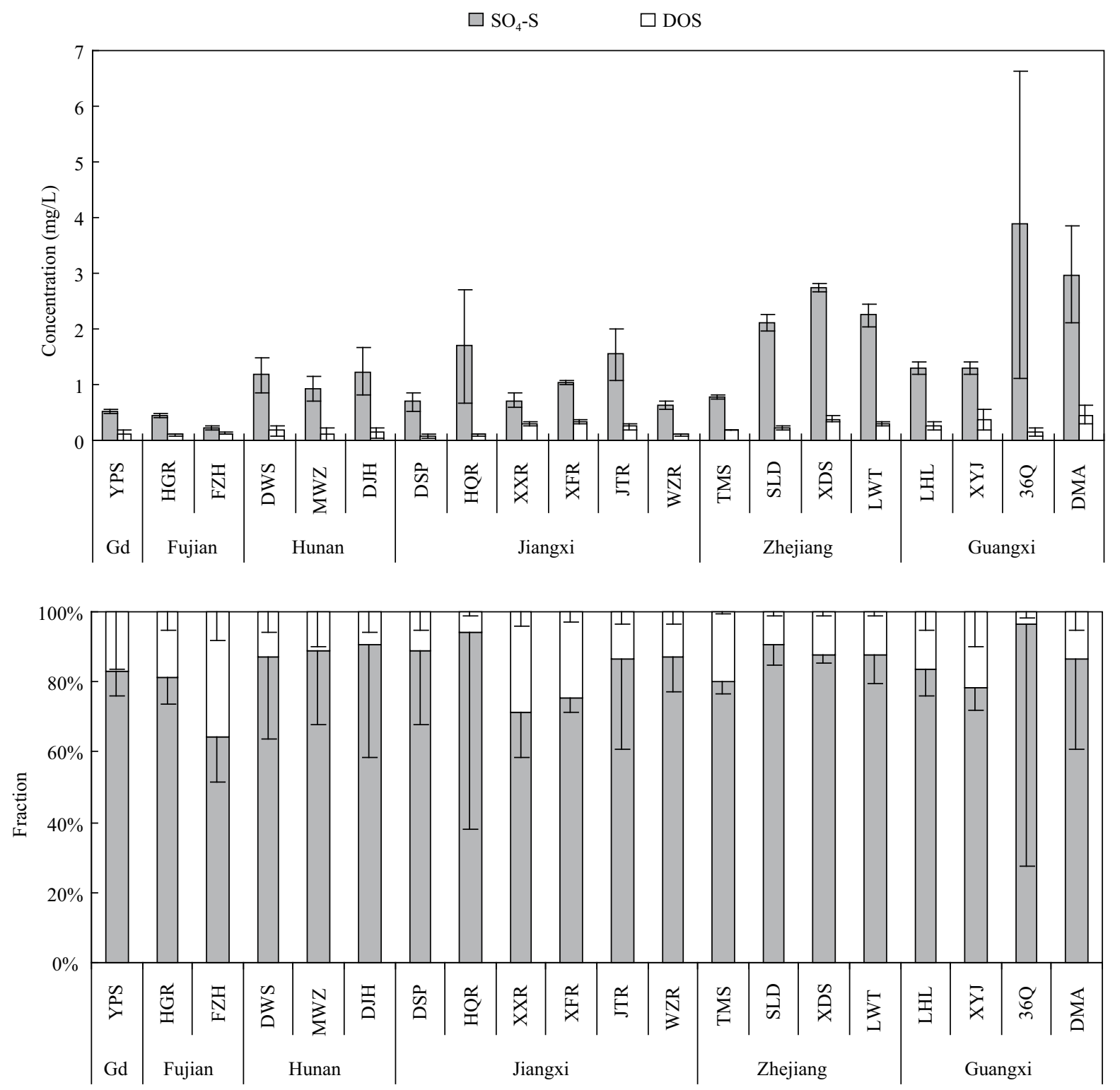

Fig. 2 Concentrations and fractions of DOS and sulfate at sites with dissolved sulfur level less than $10 \mathrm{mg} / \mathrm{L}$ (Gd denotes Guangdong). 


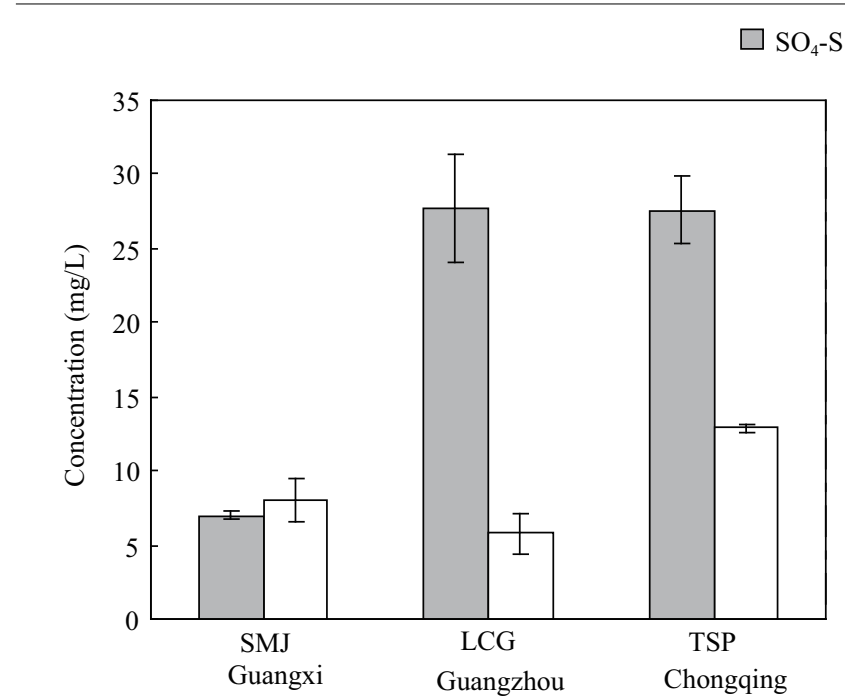

$\square \operatorname{DOS}$

Fig. 3 Concentrations (a) and fractions (b) of DOS and sulfate at sites with dissolved sulfur level higher than $10 \mathrm{mg} / \mathrm{L}$.

\subsection{Seasonal variations of DOS and sulfate concentra-} tions in stream water

Monthly mean concentrations of DOS and sulfate in stream water at YLS and MJW sites were used to study the seasonal variation of dissolved sulfur. The sites YLS and MJW have sub-tropical monsoonal climate with a cold and dry winter and warm and wet summer.

The results showed clear seasonal variation in stream water at YLS (Fig. 4). The concentrations of sulfate remained high except during the fall, when the concentration dropped to less than $1.5 \mathrm{mg} / \mathrm{L}$. The absolute and relative amounts of DOS in stream water were generally decreased along with decreasing amount of rain and temperature, with low values during the cold winter months (January and February) and high during the hot summer months

$\square \mathrm{SO}_{4}-\mathrm{S}$
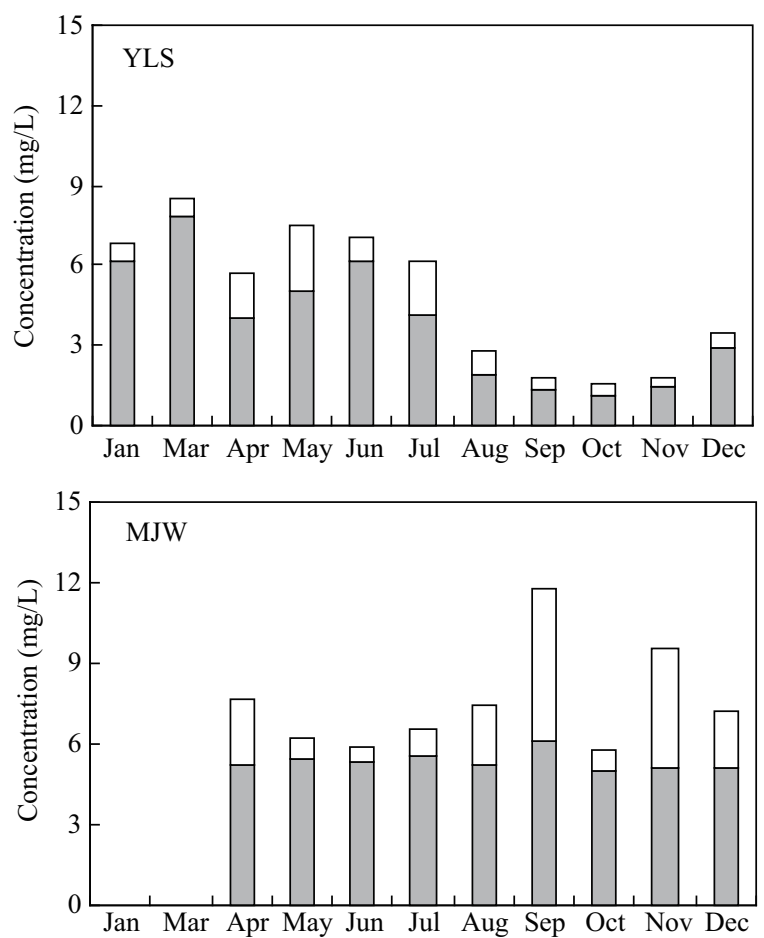

(Fig. 4). A maximum concentration of $2.4 \mathrm{mg} / \mathrm{L}$ for DOS was measured in May. The concentrations of dissolved sulfur was higher in summer than those in winter, which maybe caused by the persistent high temperature and drought in summer 2009 in Hu'nan Province (Luo et al., 2010).

Data were lacked for the winter months at MJW due to non-perennial flow. In the data available, the concentration of sulfate remained rather stable (basically from 5 to 6 $\mathrm{mg} / \mathrm{L}$ ), which may be caused by the adsorption of soil and absorption of biology. While the concentrations of DOS varied rather oppositely to what was found at YLS. The concentration of DOS was generally lower during early spring than that in the fall. The minimum and maximum concentrations of DOS were found in June $(<1 \mathrm{mg} / \mathrm{L})$ and

$\square$ DOS
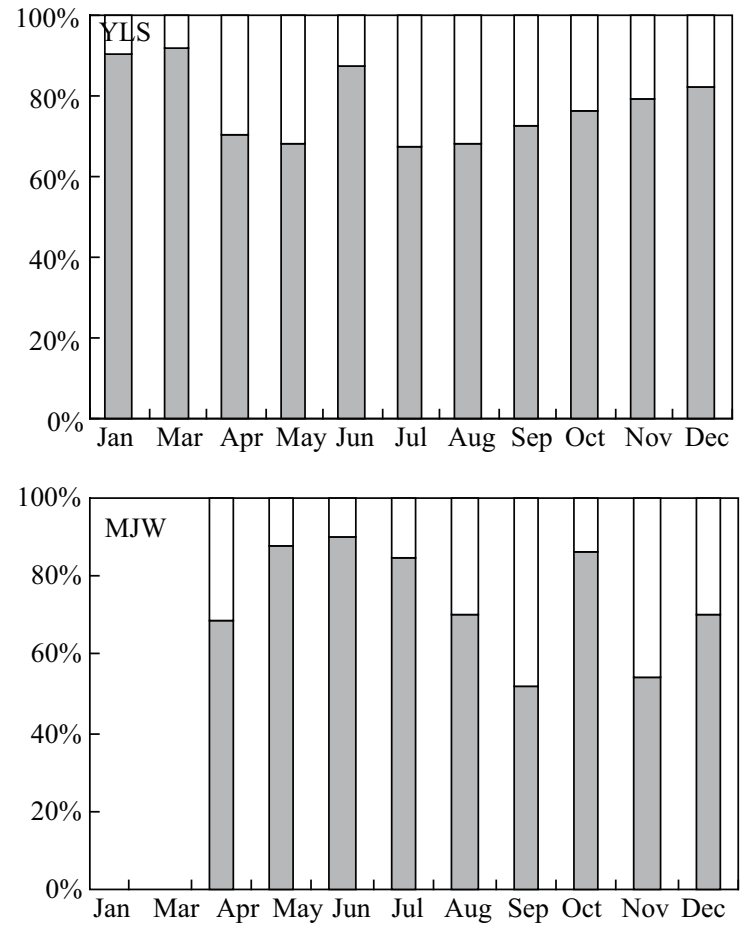

Fig. 4 Seasonal variation of dissolved sulfur at YLS in Changsha and at MJW in Hangzhou. 
in September $(5.7 \mathrm{mg} / \mathrm{L})$, respectively.

The differences of DOS concentrations in stream waters between catchments YLS and MJW might attributed to more influenced by heavy precipitation in MJW, and May to July is the rainy season with 250 to $300 \mathrm{~mm} /$ month rainfall in Hangzhou (Jin et al., 2010). The low DOS concentrations during these rainy seasons are therefore likely due to an overall dilution caused by the large amounts of rain water. In general, no consistent trends were found for the DOS concentrations in the streams at these two catchments. The seasonal variations of DOS in stream water still need to be further studied.

\subsection{Factors influencing the DOS concentration}

Stepwise multiple linear regressions were employed to empirically identify parameters governing the spatial variation in DOS concentrations. In the method, DOS was selected as dependent variable while $\mathrm{DOC}, \mathrm{SO}_{4}^{2-}, \mathrm{NO}_{3}^{-}$, $\mathrm{K}^{+}, \mathrm{Na}^{+}, \mathrm{Ca}^{2+}, \mathrm{Mg}^{2+}, \mathrm{NH}_{4}^{+}$of surface waters and total carbon, total nitrogen, total sulfur of soils in the catchment were selected as possible independent variables. $\mathrm{SO}_{4}^{2-}$ along with $\mathrm{Mg}^{2+}$ in waters and total sulfur in the soils were found to be the significant factors in the model. Together they are able to explain $89 \%$ of the spatial variation in DOS (Table 2).

A significant co-variation between several independent variables in the correlation matrix of stepwise regression may have a confounding influence on the multiple regression results (Table 3). The data were therefore also analyzed using partial least squares regression. This anal- ysis confirms that $\mathrm{SO}_{4}^{2-}$ in streams and total sulfur in surface layers soils play a governing role, and also suggests that $\mathrm{NO}_{3}^{-}$and $\mathrm{DOC}$ also may play a significant role in governing the concentration of DOS, having variable importance in the projection greater than 1.0. Furthermore, $\mathrm{Ca}^{2+}$ was found to be more important by the partial least squares analysis and the index of $\mathrm{Mg}^{2+}$ changed into a positive relation (Fig. 5) comparing with the results from the stepwise multiple linear regressions. The indexes of $\mathrm{SO}_{4}^{2-}$ based on the two methods were similar. While the reason that $\mathrm{Mg}^{2+}$ and $\mathrm{Ca}^{2+}$ are positively correlated to DOS in the multiple regression is due to that they, as the major counter ions to the dominant anion sulfate, are inherently and positively correlated to $\mathrm{SO}_{4}^{2-}(r=0.76$ and 0.96 , respectively. As shown in Table 3). Both stepwise multiple linear and partial least square regressions showed the influence of stream sulfate and soil sulfur on DOS. Conceptually, sulfur deposition is the main source for these two sulfur pools in non-sulfate soil region. Therefore, sulfur deposition probably contributes to the leaching of DOS. This is the possible reason for high DOS concentrations at three sites (i.e. LCG, SMJ and TSP) receiving high sulfur deposition.

DOC is conceptually expected to be an explanatory parameter for DOS as both parameters are inherently related to the amount of DNOM. A study by Homann et al. (1990) found a strong relationship between DOC and DOS in various water compartments of temperate forests and that DOS was leached out together with DOC into stream water.

Table 2 Stepwise multiple linear regressions results

\begin{tabular}{|c|c|c|c|c|c|c|c|}
\hline Model & Predictor in model & $B$ & SE & $P$ & $R$ & Adjusted $R^{2}$ & $R^{2}$ change \\
\hline \multirow[t]{2}{*}{1} & (Constant) & 0.29 & 0.62 & 0.64 & \multirow[t]{2}{*}{0.64} & \multirow[t]{2}{*}{0.41} & \multirow[t]{2}{*}{0.41} \\
\hline & $\mathrm{SO}_{4}^{2-}$ & 0.12 & 0.03 & 0.00 & & & \\
\hline \multirow[t]{3}{*}{2} & (Constant) & 0.88 & 0.46 & 0.07 & \multirow[t]{3}{*}{0.85} & \multirow[t]{3}{*}{0.72} & \multirow[t]{3}{*}{0.31} \\
\hline & $\mathrm{SO}_{4}^{2-}$ & 0.44 & 0.08 & 0.00 & & & \\
\hline & $\mathrm{Mg}^{2+}$ & -2.21 & 0.48 & 0.00 & & & \\
\hline \multirow{4}{*}{3} & (Constant) & -0.86 & 0.78 & 0.29 & \multirow{4}{*}{0.89} & \multirow[t]{4}{*}{0.80} & \multirow[t]{4}{*}{0.08} \\
\hline & $\mathrm{SO}_{4}^{2-}$ & 0.38 & 0.07 & 0.00 & & & \\
\hline & $\mathrm{Mg}^{2+}$ & -1.88 & 0.44 & 0.00 & & & \\
\hline & Total sulfur & 53.10 & 20.43 & 0.02 & & & \\
\hline
\end{tabular}

Predictor in model: variables selected into the model; $B$ : partial regression coefficient; SE: standard errors.

Table 3 Correlation matrixes between DOS and anion, cation, DOC in streams or total carbon (TC), total nitrogen (TN), total sulfur (TS) in soil

\begin{tabular}{|c|c|c|c|c|c|c|c|c|c|c|c|c|c|c|}
\hline & $\mathrm{pH}$ & $\mathrm{Na}^{+}$ & $\mathrm{NH}_{4}^{+}$ & $\mathrm{K}^{+}$ & $\mathrm{Mg}^{2+}$ & $\mathrm{Ca}^{2+}$ & $\mathrm{F}^{-}$ & $\mathrm{Cl}^{-}$ & $\mathrm{NO}_{3}^{-}$ & $\mathrm{SO}_{4}^{2-}$ & DOC & $\mathrm{TC}$ & $\mathrm{TN}$ & TS \\
\hline DOS & -0.01 & 0.07 & 0.06 & 0.25 & 0.45 & 0.63 & -0.05 & 0.14 & 0.48 & $0.64 * *$ & -0.10 & $0.59 * *$ & $0.46^{*}$ & $0.057 * *$ \\
\hline $\mathrm{pH}$ & 1 & 0.04 & 0.33 & $0.04 *$ & $0.50 * *$ & $0.56 *$ & 0.15 & -0.12 & 0.05 & $0.38 *$ & 0.14 & -0.31 & -0.23 & -0.15 \\
\hline $\mathrm{Na}^{+}$ & & 1 & 0.11 & $0.57^{* * *}$ & 0.20 & 0.15 & 0.30 & $0.93 * * *$ & 0.17 & 0.20 & 0.36 & -0.14 & -0.23 & -0.16 \\
\hline $\mathrm{NH}_{4}^{+}$ & & & 1 & $0.36^{*}$ & $0.52 * *$ & 0.21 & -0.10 & -0.01 & -0.22 & $0.44 *$ & 0.25 & 0.09 & 0.02 & 0.17 \\
\hline $\mathrm{K}^{+}$ & & & & 1 & $0.66^{* * * *}$ & $0.38 * *$ & $0.41 *$ & $0.42 *$ & 0.17 & $0.59 * *$ & $0.58 * *$ & -0.04 & -0.20 & 0.04 \\
\hline $\mathrm{Mg}^{2+}$ & & & & & 1 & $0.68 * * *$ & 0.09 & 0.15 & 0.22 & $0.96^{* * *}$ & 0.30 & 0.15 & 0.03 & 0.16 \\
\hline $\mathrm{Ca}^{2+}$ & & & & & & 1 & 0.02 & 0.16 & $0.62 * *$ & $0.76^{* * *}$ & 0.08 & 0.03 & 0.01 & 0.05 \\
\hline $\mathrm{F}^{-}$ & & & & & & & 1 & 0.12 & 0.06 & $0.03 * *$ & $0.43 *$ & -0.21 & -0.22 & -0.09 \\
\hline $\mathrm{Cl}^{-}$ & & & & & & & & 1 & 0.24 & 0.20 & 0.25 & -0.06 & -0.15 & -0.16 \\
\hline $\mathrm{NO}_{3}^{-}$ & & & & & & & & & 1 & $0.39 *$ & -0.06 & 0.04 & 0.04 & -0.08 \\
\hline $\mathrm{SO}_{4}^{2-}$ & & & & & & & & & & 1 & 0.22 & 0.29 & 0.14 & 0.25 \\
\hline DOC & & & & & & & & & & & 1 & -0.24 & $-0.43^{*}$ & $-0.46 *$ \\
\hline $\mathrm{TC}$ & & & & & & & & & & & & 1 & $0.93^{* * *}$ & $0.77 * * *$ \\
\hline $\mathrm{TN}$ & & & & & & & & & & & & & 1 & $0.77 * * *$ \\
\hline TS & & & & & & & & & & & & & & 1 \\
\hline
\end{tabular}

***, **, $*$ Significance at level $p<0.001, p<0.01, p<0.05$, respectively. 

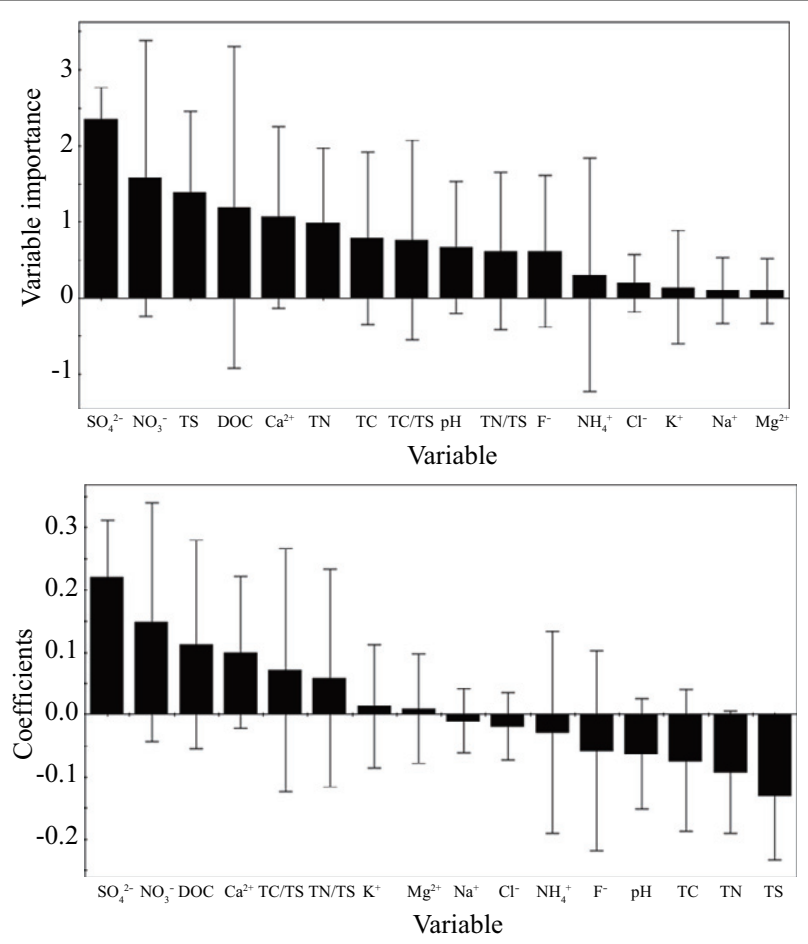

Fig. 5 Variable importance and coefficients in the projection of partial least squares regression.

\section{Conclusions}

Dissolved organic sulfur and sulfate in stream waters from forested catchments were studied in southern China. It was found that DOS concentration in all the streams ranged from 0 to $13.1 \mathrm{mg} / \mathrm{L}$ (average $1.3 \mathrm{mg} / \mathrm{L}$ ), while $\mathrm{SO}_{4}-\mathrm{S}$ ranged from 0.2 to $33.6 \mathrm{mg} / \mathrm{L}$ (average $3.9 \mathrm{mg} / \mathrm{L}$ ). The DOS concentrations of water samples in most sites were below $1 \mathrm{mg} / \mathrm{L}$. High concentrations of DOS were found in the sites that are exposed to a heavy acid rain loading and therefore had high $\mathrm{SO}_{4}^{2-}$ concentrations in streams. The DOS constituted less than $60.1 \%$ of dissolved sulfur (average 17.9\%) in all the streams. The concentration of DOS in streams water varied with seasons, and wasn't found consistent trend at two studied catchments. Multivariate statistics showed that the DOS concentration was correlated to $\mathrm{SO}_{4}^{2-}$ in streams and total sulfur in surface layers soils. These implied that high long-term load of sulfate deposition facilitated the sulfate accumulation in forest soil and then increased the concentration and fraction of DOS in stream waters in acid rain prevailing regions.

\section{Acknowledgments}

This work was supported by the Program "Nitrogen Cycling Processes and their Environmental Consequence in Subtropical Catchments of China", Chinese Academy of Sciences (No. KZCX2-YW-GJ01), the National Basic Research Program (973) of China (No. 2005CB422206), and the State Key Laboratory of Urban and Regional Ecology.

\section{References}

Amirbahman A, Reid A L, Haines T A, Kahl J S, Arnold C, 2002. Association of methylmercury with dissolved humic acids. Environmental Science $\mathcal{E}$ Technology, 36(4): 690-695.

Chen Z, Liu Z, 1996. Research on Acid Rain in China. China Environmental Science Press, Beijing. 24-30.

Christou M, Avramides E J, Jones D L, 2006. Dissolved organic nitrogen dynamics in a Mediterranean vineyard soil. Soil Biology $\mathcal{G}$ Biochemistry, 38(8): 2265-2277.

David M B, Mitchell M J, 1985. Sulfur constituents and cycling in waters, seston, and sediments of an oligotrophic lake. Limnology and Oceanography, 30(6): 1196-1207.

Dawson H J, Ugolini F C, Hrutfiord B F, Zachara J, 1978. Role of soluble organics in the soil processes of a podzol, Central Cascades, Washington. Soil Science, 126(5): 290-296.

Galloway J N, Norton S A, Church M R, 1983. Freshwater acidification from atmospheric deposition of sulfuric acid: a conceptual model. Environmental Science E Technology, 17(11): 541-545.

Guo J H, Zhang X S, Vogt R D, Xiao J S, Zhao D W, Xiang R J et al., 2007. Evaluating controlling factors to Ali/(Ca $+\mathrm{Mg})$ molar ratio in acidic soil water, southern and southwestern China: multivariate approach. Environmental Monitoring and Assessment, 129(1-3): 321-329.

Haitzer M, Aiken G R, Ryan J N, 2002. Binding of mercury(II) to dissolved organic matter: the role of the mercury-to-DOM concentration ratio. Environmental Science E Technology, 36(16): 3564-3570.

Homann P S, Mitchell M J, van Miegroet H, Cole D W, 1990. Organic sulfur in throughfall, stem flow, and soil solutions from temperate forests. Canadian Journal of Forest Research, 20(9): 1535-1539.

Houle D, Carignan R, Lachance M, Dupont J, 1995. Dissolved organic carbon and sulfur in southwestern Quebec lakes: relationships with catchment and lake properties. Limnology and Oceanography, 40(4): 710-717.

Jin X Y, Shao X Q, Tao Y G, 2010. Analysis of characteristics and space-time distribution of plum rains in Zhejiang province. Journal of China Hydrology, 30(3): 93-97.

Jones D L, Shannon D, Murphy D V, Farrar J, 2004. Role of dissolved organic nitrogen (DON) in soil $\mathrm{N}$ cycling in grassland soils. Soil Biology E Biochemistry, 36(5): 749756.

Kalbitz K, Popp P, Geyer W, Hanschmann G, 1997. $\beta-\mathrm{HCH}$ mobilization in polluted wetland soils as influenced by dissolved organic matter. Science of the Total Environment, 204(1): 37-48.

Kalbitz K, Solinger S, Park J, Michalzik B, Matzner E, 2000. Controls on the dynamics of dissolved organic matter in soils: a review. Soil Science, 165(4): 277-304.

Kroeger K D, Cole M L, Valiela I, 2006. Groundwatertransported dissolved organic nitrogen exports from coastal watersheds. Limnology and Oceanography, 51(5): 22482261.

Larssen T, Lydersen E, Tang D G, He Y, Gao J X, Liu H Y et al., 2006. Acid rain in China. Environmental Science $\mathcal{E}$ Technology, 40(2): 418-425.

Lorite-Herrera M, Hiscock K, Jiménez-Espinosa R, 2009. Distribution of dissolved inorganic and organic nitrogen in river water and groundwater in an agriculturally-dominated catchment, south-east Spain. Water, Air, E Soil Pollution, 198(1-4): 335-346.

Luo B L, Peng L L, Zhang C, 2010. Persistent high temperature 
and drought feature and anomalies of atmospheric circulation in August 2009 in Hu'nan province. Journal of Arid Meteorology, 28(1): 20-28.

Marschner B, 1998. DOM-enhanced mobilization of benzo (a) pyrene in a contaminated soil under different chemical conditions. Physics and Chemistry of the Earth, 23(2): 199203.

Mitchell M J, David M B, Maynard D G, Telang S A, 1986. Sulfur constituents in soils and streams of a watershed in the rocky mountains of Alberta. Canadian Journal of Forest Research, 16(2): 315-320.

Mitchell M J, Driscoll C T, Fuller R D, David M B, Likens G E, 1989. Effect of whole-tree harvesting on the sulfur dynamics of a forest soil. Soil Science Society of America Journal, 53(3): 933-940.

Neff J C, Chapin F S III, Vitousek P M, 2003. Breaks in the cycle: dissolved organic nitrogen in terrestrial ecosystems. Frontiers in Ecology and the Environment, 1(4): 205211.

Nilsson S I, Andersson S, Valeur I, Persson T, Bergholm J, Wirén A, 2001. Influence of dolomite lime on leaching and storage of $\mathrm{C}, \mathrm{N}$ and $\mathrm{S}$ in a spodosol under Norway spruce (Picea abies (L.) Karst.). Forest Ecology and Management, 146(13): 55-73.

Peuravuori J, Monteiro A, Eglite L, Pihlaja K, 2005. Comparative study for separation of aquatic humic-type organic constituents by DAX-8, PVP and DEAE sorbing solids and tangential ultrafiltration: elemental composition, sizeexclusion chromatography, UV-vis and FT-IR. Talanta, 65(2): 408-422.

Prietzel J, Cronauer H, Strehl C, 1996. Determination of dissolved total sulfur in aqueous extracts and seepage water of forest soils. International Journal of Environmental Analytical Chemistry, 64(3): 193-203.
Prietzel J, Mayer B, Legge A H, 2004. Cumulative impact of 40 years of industrial sulfur emissions on a forest soil in westcentral Alberta (Canada). Environmental Pollution, 132(1): 129-144.

Raue B, Brauch H, Frimmel F H, 1991. Determination of sulphate in natural waters by ICP/OES-comparative studies with ion chromatography. Fresenius' Journal of Analytical Chemistry, 340(6): 395-398.

Raulund-Rasmussen K, Borggaard O K, Hansen H C B, Olsson M, 1998. Effect of natural organic soil solutes on weathering rates of soil minerals. European Journal of Soil Science, 49(3): 397-406.

Skyllberg U, Xia K, Bloom P R, Nater E A, Bleam W F, 2000. Binding of mercury (II) to reduced sulfur in soil organic matter along upland-peat soil transects. Journal of Environmental Quality, 29(3): 855-865.

Temminghoff E J M, Van der Zee S E A T M, De Haan F A M, 1997. Copper mobility in a copper-contaminated sandy soil as affected by $\mathrm{pH}$ and solid and dissolved organic matter. Environmental Science $\mathcal{E}$ Technology, 31(4): 1109-1115.

Wang J K, Solomon D, Lehmann J, Zhang X D, Amelung W, 2006. Soil organic sulfur forms and dynamics in the Great Plains of North America as influenced by long-term cultivation and climate. Geoderma, 133(3-4): 160-172.

Wu F C, Jin X C, Zhang R Y, Liao H Q, Wang S R, Jiang X et al., 2010. Effects and significance of organic nitrogen and phosphorous in the lake aquatic environment. Journal of Lake Sciences, 22(1): 1-7.

Yue L X, Wu F C, Chen W L, 2008. Changes in molecular weight distribution of dissolved organic matter with depth in Lake Baihua. Environmental Science and Management, 33(5): 66-70.

Zsolnay Á, 2003. Dissolved organic matter: artefacts, definitions, and functions. Geoderma, 113(3-4): 187-209. 